\title{
POLA MAKAN PASIEN RAWAT JALAN DM TIPE 2 DI RUMAH SAKIT PENDIDIKAN UNHAS
}

\section{DIETARY OF DM TYPE 2 OUTPATIENT AT HASANUDDIN UNIVERSITY HOSPITAL}

\author{
Devy Febrianti ${ }^{1}$, Ridwan M Thaha ${ }^{2}$, Healty Hidayanty ${ }^{3}$ \\ ${ }^{1}$ Bagian Promosi Kesehatan, Fakultas Kesehatan Masyarakat, Universitas Hasanuddin \\ ${ }^{2}$ Bagian Promosi Kesehatan, Fakultas Kesehatan Masyarakat, Universitas Hasanuddin \\ ${ }^{3}$ Bagian Gizi, Fakultas Kesehatan Masyarakat, Universitas Hasanuddin \\ Email Korespondensi: khuink@gmail.com
}

\begin{abstract}
ABSTRAK
Diabetes Melitus (DM) merupakan penyakit menahun yang akan di derita seumur hidup yang di kenal dengan penyakit kencing manis, dan di juluki "the mother of disease" penyakit ini disebut penyakit metabolic yang ditandai hyperglekemia kronik dengan gangguan metabolisme karbohidrat, lemak dan protein yang berkaitan dengan kelainan sekresi insulin. Penelitian ini bertujuan untuk mengetahui pola makan penderita DM type 2. Sebuah Penelitian kuantitatif dengan metode cross sectional. Wawancara di lakukan pada 58 penderita DM type 2 dari 98 total penderita DM di poli interna Rumah Sakit Pendidikan Unhas. Untuk melihat hubungan Health Belief Model terhadap pola makan pendeita DM type 2, data di analisis dengan menggunakan aplikasi Nutrisuvery versi Indonesia dan uji chi-square pada aplikasi SPSS. Hasil penelitian menunjukkan hubungan pengetahuan dengan ancaman yang dirasakan adalah ( $\mathrm{p}$ value $=0.391$ ), hubungan manfaat yang dirasakan dengan asupan Energi $(\mathrm{p}$ value $=0.001)$, asupan Karbohidrat $(\mathrm{p}$ value $=$ 0.003 ), asupan protein ( $\mathrm{p}$ value $=0.012)$, dan asupan Lemak ( $\mathrm{p}$ value $=0.019)$, hubungan ancaman yang dirasakan dengan Asupan Energi ( $\mathrm{p}$ value $=0.342)$, asupan Karbohidrat ( $\mathrm{p}$ value $=0.012)$, asupan protein $(\mathrm{p}$ value $=0.005)$, dan asupan Lemak ( $\mathrm{p}$ value $=0.015$ ). Kepada pihak Rumah Sakit Pendidikan Unhas agar melakukan edukasi kepada penderita DM type 2 tentang pola makan dan asupan zat gizi.
\end{abstract}

Kata Kunci : Diabetes Melitus Type 2, Health Belief Model, Pola Makan, Asupan Zat Gizi Makro

\section{ABSTRACT}

Diabetes Mellitus (DM) is a chronic disease which will be suffered for long life that is known as diabetes, and it is called as "the mother of disease". This disease is known as metabolic disease which is marked by chronic hyperglicemia with carbohydrate, lipid, and protein metabolism disruption that are related to insulin secretion disorder. This study aims to know dietary of DM type 2 patient. A quantitative study by cross-sectional method. The interview was done for 58 patients of DM type 2 pf 98 total DM patients at interna polyclinic of Hasanuddin University Hospital. To know the relation of health belief model toward dietary DM type 2 patient, data were analysed by Nutrisurvey Indonesian Version and chi-square on SPSS aplication. Result of the study revealed the relation of knowledge and perceived threat were $(p$ value $=0.391)$, relation of perceived benefit and energy intake ( $p$ value $=$ $0.001)$, carbohydrate intake ( $p$ value $=0.003)$, protein intake ( $p$ value 0.012), lipid intake $(p$ value $=0.019)$. The relation of perceied threat and energy intake ( $p$ value $=0.342)$, carbohydrate intake ( $p$ value $=0.012)$, protein intake ( $p$ value $=0.005)$, and lipid intake ( $p$ value $=0.015)$. To party of Hasanuddin University Hospital for doing the education to DM type 2 patient about dietary and nutrition intake.

Keywords : Diabetes Mellitus Type 2, Health Belief Model, Dietary, Macro Nutrition Intake 


\section{PENDAHULUAN}

Pembangunan kesehatan di Indonesia saat ini dihadapkan pada dua masalah ganda (double burden). Disamping masalah penyakit menular dan kurang gizi, terjadi pula peningkatan kasus penyakit tidak menular (PTM) dan obesitas (gizi lebih) yang merupakan faktor risiko terjadinya PTM seperti diabetes mellitus, kardiovaskular, strok, hipertensi dan lain-lain. Faktor sosial ekonomi, serta adanya perubahan gaya hidup diduga telah menyebabkan peningkatan kasus penyakit tidak menular dalam hal ini diabetes melitus di Indonesia khususnya Kota Makassar (PERKENI, 2015).

Diabetes Melitus (DM) merupakan penyakit menahun yang akan diderita seumur hidup. Dalam pengelolaan penyakit tersebut, selain dokter perawat, ahli gizi dan tenaga kesehatan lainnya, peran pasien dan keluarga menjadi sangat penting. Edukasi kepada pasien dan keluarganya bertujuan dengan memberikan pemahaman tentang perjalanan penyakit dan pencegahannya. Penyakit diabetes mellitus (DM) dikalangan masyarakat dikenal dengan penyakit kencing manis juga dijuluki "the mother of disease" (Ndraha, 2014).

Jenis DM yang paling banyak diderita dan prevalensinya terus meningkat adalah DM tipe 2 dengan kasus terbanyak yaitu 90\% dari seluruh kasus DM di dunia (WHO, 2013). Kejadian DM tipe 2 pada wanita lebih tinggi daripada laki-laki, karena secara fisik wanita memiliki peluang peningkatan indeks massa tubuh yang lebih besar (Green, 2012).

Data Kementrian Kesehatan menyatakan bahwa tingkat PTM di Makassar melampaui prevalensi rata-rata nasional untuk kasus DM sendiri mencapai 5,3\% sementara data nasionalnya hanya 2,1 persen. Data surveilans Penyakit tidak menular Bidang P2PL Dinas Kesehatan Provinsi Sulawesi Selatan tahun 2015 terdapat DM 17.843 kasus di Kota Makassar (Dinas Kesehatan Provinsi Sulsel, 2015).

Data rekam medik Rumah Sakit Pendidikan UNHAS Kota Makassar pada tahun 2015-2017 terjadi peningkatan dengan rincian jumlah pasien 2015 sebanyak 1.058 penderita, 2016 sebanyak 1.148 penderita dan pada tahun 2017 sebanyak 1.213 penderita. Sedangkan jumlah kunjungan pada tahun 2015 sebanyak 2.343 kunjungan, 2016 sebanyak 2.563 kunjungan, dan pada tahun 2017 sebanyak 2.687 kunjungan.

Ancaman diabetes dapat dihadapi dengan pencegahan terutama yang berkaitan dengan pencegahan primer. Pencegahan primer adalah upaya yang ditujukan pada kelompok yang memiliki faktor risiko, yakni mereka yang belum pernah terkena, tetapi 
berpotensi untuk mendapat diabetes mellitus.

Perilaku pencegahan terutama terhadap faktor risiko yang dapat dimodifikasi yaitu pola makan dan aktivitas fisik (Rizqi, 2017).

Berkaitan dengan modifikasi perilaku, pengetahuan dan sikap merupakan faktor yang sangat penting bagi perubahan perilaku seseorang. Dengan demikian, pengetahuan dan sikap yang baik tentang diabetes mellitus dan pencegahannya sangat diperlukan guna terbentuknya perilaku pencegahan dalam pola makan dan aktifitas fisik yang baik (Rizka, 2012).

Tentang perilaku makan, penduduk terutama daerah perkotaan telah berubah dari pola tradisional ke pola modern dengan mengonsumsi makanan apa yang di inginkan tanpa memperhatikan kandungan nilai zat gizi makanan mulai dari kandungan lemak, gula, garam dan disisi lain tidak cukup mengkonsumsi sayur dan buah sebagai sumber serat. Disamping itu kebiasaan minum minuman berkafein turut melengkapi perilaku makan berisiko ini (Media Gizi Masyarakat Indonesia, 2011).

Berdasarkan uraian diatas peneliti bermaksud untuk meneliti tentang perilaku pola makan penderita DM dengan berdasarkan teori Health Belief Model yang berdasarkan pada proses terjadinya perubahan perilaku dalam Health Belief
Model (HBM), perilaku akan berubah salah satunya yaitu individu diberikan pemahaman tentang keuntungannya. Dicari dulu penyebab dari suatu perilaku yang kurang baik, lalu diberikan penyuluhan serta informasi yang terinci tentang keuntungan dari perbaikan perilakunya.

\section{BAHAN DAN METODE}

\section{Lokasi dan Rancangan penelitian}

Penelitian ini dilakukan di Rumah Sakit Pendidikan UNHAS pada bulan Agustus sampai September 2018. Alasan memilih lokasi ini karena adanya data yang diperoleh dari rekam medic Rumah Sakit Pendidikan Unhas sejak tahun 2014-2017 menunjukkan peningkatan kasus Diabetes Melitus Type 2. Hal ini diperkuat dengan melihat perilaku gaya hidup di perkotaan khususnya Kota Makassar. Jenis penelitian ialah kuantitatif dengan pendekatan desain penelitian cross sectional. Dalam rancangan ini peneliti melakukan observasi pada subjek untuk mengetahui hubungan antar variabel.

\section{Populasi dan Sampel}

Populasi adalah semua penderita DM yang merupakan pasien rawat jalan Poli Interna Rumah Sakit Pendidikan Unhas yang memenuhi kriteria inklusi dan eksklusi. Jumlah populasi penderita DM yang melakukan pemeriksaan kesehatan di poli Interna RS Pendidikan Unhas selama masa 
Febrianti,2020

penelitian Agustus-September 2018 berjumlah 98 orang.

Sampel penelitian adalah sebagaian penderita DM Type 2 yang melakukan pemeriksaan kesehatannya di Poli Interna RS Pendidikan Unhas. Sampel di ambil dengan menggunakan metode total sampling, yaitu semua populasi yang telah memenuhi kriteria inklusi dan eksklusi di gunakan sebagai sampel (Sugiyono, 2005). Sampel yang di gunakan sebanyak 58 orang. Sampel ini telah memenuhi beberapa kriteria di antaranya : (a). Kriteria inklusi dalam penelitian ini adalah (1) penderita DM type 2 dibuktikan dengan diagnosa dari buku status rekam medik (laporan RS); (2) penderita DM type 2 yang berusia 30-80 tahun dan bersedia secara suka rela dan tertulis (Informed consent) menjadi responden; (3) penderita DM type 2 yang bisa baca tulis; (4) pendidikan min SMP; (5) penderita DM type 2 yang tidak memliki komplikasi serius (retinopati, gangrene/ulkus diabetikum, gagal ginjal kronis); (b) Kriteria eksklusi dalam penelitian ini adalah penderita DM selain penderita DM type 2 yang memiliki komplikasi penyakit serius dan mengalami gangguan kejiwaan.

\section{Metode Pengumpulan Data}

Pengumpulan data dilakukan langsung oleh peneliti. Pengumpulan data primer diperoleh dari instrumen penelitian (kuesioner) yang telah diisi oleh responden Instrumen yang digunakan dalam penelitian ini adalah kuesioner untuk mengukur perilaku pola makan penderita DM type 2 . Instrumen ini terdiri dari sejumlah poin pertanyaan terkaitan dengan variabel dependen terhadap variabel, pengetahuan, sikap dan tindakan..

\section{Analisis Data}

Data yang diperoleh diolah secara komputerisasi, dengan menggunakan program SPSS (Statistik Product and Service Solution) meliputi editing, scoring, entry, cleaning dan menggunakan program Nutrisurvei versi Indonesia. Analisis univariat digunakan untuk mendapatkan gambaran umum dengan mendeskripsikan distrubusi frekuensi dari masing- masing variabel independen pada penelitian yang disajikan dalam bentuk tabel distribusi frekuensi.

Analisi bivariat dilakukan setelah analisis univariat dimana telah diketahui karakteristik atau distribusi setiap variable. Analisis bivariat dilakukan terhadap dua variable yang diduga berhubungan, analisis digunakan untuk mengetahui hubungan pengetahuan dengan ancaman pola makan, manfaat yang di rasakan dengan pola makan dan ancaman yang dirasakan dengan pola makan pada penderita DM type 2 pasien 
rawat jalan rumah sakit pendidikan unhas dengan menggunakan uji chi-square. Data yang telah dianalisis disajikan dalam bentuk tabel dan disertai dengan narasi untuk membahas aspek penelitian

\section{HASIL}

\section{Karakteristik Responden}

Berdasarkan tabel 1 menunjukkan bahwa responden terbanyak adalah jenis kelamin laki-laki dengan jumlah 31 orang $(53.2 \%)$ dan responden perempuan berjumlah 27 orang (46.6\%). Karakteristik responden berdasarkan usia yang terbanyak pada kelompok umur 51-60 tahun dengan jumlah 24 orang (41.4\%) dan pada kelompok umur 30-40 tahun merupakan responden dengan kelompok umur paling sedikit dengan jumlah 4 orang $(6.9 \%)$.

Karakteristik responden berdasarkan tingkat pendidikan yang paling banyak merupakan tamatan SMA dengan jumlah 32 orang $(55.2 \%)$ dan responden dengan pendidikan perguruan tinggi berjumlah 26 orang (44.8\%). Karakteristik responden berdasarkan pekerjaan yaitu sebanyak 20 responden $(34.5 \%)$ dengan pekerjaan lainnya (IRT, tidak bekerja, dan pensiunan) dan yang paling sedikit adalah berprofesi sebagai TNI/Polri sebanyak 2 orang (3.4\%)

Tabel 1. Distribusi responden berdasarkan karakteristik umum.

\begin{tabular}{lcc}
\hline \multicolumn{1}{c}{ Karakteristik responden } & \multicolumn{2}{c}{ Penderita DM } \\
\cline { 2 - 3 } Jenis Kelamin & 31 & \\
-Laki-laki & 27 & 53.4 \\
-Perempuan & $56( \pm 10.32)$ & 46.6 \\
\hline Usia mean $( \pm$ SD) & 4 & 6.9 \\
- 30-40 tahun & 9 & 15.5 \\
- 41-50 tahun & 24 & 41.4 \\
- 51-60 tahun & 21 & 36.2 \\
- >61 tahun & & \\
\hline Pendidikan & 32 & 55.2 \\
- SMA & 26 & 44.8 \\
- PT & & \\
\hline Pekerjaan & 6 & 10.3 \\
- PNS & 12 & 20.0 \\
- Peg Swasta/BUMN & 2 & 3.4 \\
- TNI/POLRI & 18 & 31.0 \\
- Wiraswasta & 20 & 34.5 \\
- Lainnya & & \\
\hline
\end{tabular}

Sumber: Data Primer

Pengetahuan Pola Makan dengan 2 Ancaman yang dirasakan Pasien DM Tipe 
Febrianti,2020

Hubungan pengetahuan dengan pengetahuan yang baik dan merasa tidak ancaman yang dirasakan penderita DM type terancam berjumlah 30\% (12 orang) dan yang 2 akan terlihat pada tabel 2. Berdasarkan data pengetahuan cukup yang merasa tidak pada tabel 2 menunjukkan bahwa pada variabel dengan jumlah terbanyak dengan pengetahuan cukup yang merasa terancam sebanyak $77.8 \%$ (14 orang) dan untuk pengetahuan baik sebanyak $70 \%$ (28 orang) terancaman berjumlah $22.2 \%$ (4 orang), dengan nilai $p$ value $0.391>0.05$ maka dapat disimpulkan bahwa tidak ada hubungan antara pengetahuan dan ancaman yang di rasakan.

sedangkan jumlah terbanyak untuk

Tabel 2. Hubungan pengetahuan dengan ancaman yang dirasakan penderita DM type 2.

\begin{tabular}{|c|c|c|c|c|c|c|c|}
\hline \multirow[t]{3}{*}{ Pengetahuan } & \multicolumn{4}{|c|}{ Ancaman yang dirasakan } & & & \multirow{3}{*}{$\begin{array}{c}p \\
\text { value }\end{array}$} \\
\hline & \multicolumn{2}{|c|}{$\begin{array}{c}\text { Merasa } \\
\text { Terancam }\end{array}$} & \multicolumn{2}{|c|}{$\begin{array}{c}\text { Merasa } \\
\text { Tidak } \\
\text { Terancam }\end{array}$} & & llah & \\
\hline & $\mathrm{N}$ & $\%$ & $\mathrm{n}$ & $\%$ & $\mathrm{n}$ & $\%$ & \\
\hline $\begin{array}{l}\text { Pengetahuan } \\
\text { Baik }\end{array}$ & 28 & 70 & 12 & 30 & 40 & 100 & \\
\hline $\begin{array}{l}\text { Pengetahuan } \\
\text { Cukup }\end{array}$ & 14 & 77.8 & 4 & 22.2 & 18 & 100 & 0.391 \\
\hline
\end{tabular}

\section{Manfaat yang dirasakan terhadap pola Makan Pasien DM Tipe 2}

Hubungan antara manfaat yang dirasakan dengan pola makan (asupan zat gizi makro) dapat dilihat pada tabel 3. Dari tabel 3 menunjukkan bahwa penderita DM type 2 terbanyak yang memiliki asupan energi kurang dan merasakan tidak ada manfaat berjumlah $54.2 \%$ (13 orang) dan yang merasa ada manfaat sebanyak $14.7 \%$ (5 orang) sedangkan untuk penderita DM type 2 terbanyak dengan asupan energi cukup dan merasa ada manfaat sebanyak $85.3 \%$ (29 orang) sedangkan untuk yang merasa tidak ada manfaat berjumlah $45.8 \%$ (11 orang) dengan hasil statistik nilai $p$ value pada hubungan manfaat yang dirasakan dengan asupan energi $p=0.001(p<0.05)$, sehingga kita dapat meyimpulkan bahwa ada hubungan antara manfaat yang dirasakan asupan energi.

Hubungan antara manfaat yang dirasakan dengan asupan karbohidrat dan asupan protein serta lemak juga memiliki hubungan. Jumlah penderita DM Tipe 2 
terbanyak dengan asupan karbohidrat lebih dan merasa ada manfaat berjumlah 22 orang $(64,7 \%)$, dan yang tidak merasa manfaat berjumlah 6 orang (25\%), dengan hasil statistik memperoleh nilai $p$ value 0.003 $(p>0.05)$. Sehingga kita dapat meyimpulkan bahwa ada hubungan antara manfaat yang dirasakan dengan jumlah asupan karbohidrat.

Penderita DM Tipe 2 terbanyak dengan asupan protein lebih dan merasa ada manfaat berjumlah 5 orang $(14,7 \%)$ dan yang tidak ada manfaat berjumlah 1 orang $(4,2 \%)$, sehingga dengan hasil statistik nilai $p$ value 0.385 ( $p<0.05)$, dapat disimpulkan bahwa tidak ada hubungan antara manfaat yang dirasakan asupan protein. Hubungan antara manfaat yang dirasakan dengan asupan lemak memiliki hubungan. Dimana jumlah penderita DM tipe 2 dengan asupan lemak cukup dan merasa ada manfaat berjumlah 19 orang (55,9\%), sedangkan yang tidak merasakan manfaat sejumlah 6 orang $(25 \%)$ dengan nilai $p$ value $0.019(p>0.05)$.

Tabel 3. Hubungan manfaat yang dirasakan dengan pola makan (Asupan Energi) penderita DM type 2.

\begin{tabular}{ccccccccc}
\hline \multirow{2}{*}{$\begin{array}{c}\text { Manfaat yang } \\
\text { dirasakan }\end{array}$} & \multicolumn{4}{c}{ Asupan Energi } & \multicolumn{2}{c}{ Jumlah } & \multirow{2}{*}{$p$ value } \\
\cline { 2 - 6 } & \multicolumn{2}{c}{ Kurang } & \multicolumn{2}{c}{ Cukup } & & \\
\cline { 2 - 7 } & $\mathrm{N}$ & $\%$ & $\mathrm{~N}$ & $\%$ & $\mathrm{n}$ & $\%$ & \\
\hline Ada Manfaat & 29 & 85.3 & 5 & 14.7 & 34 & 100 & \\
\hline $\begin{array}{c}\text { Tidak ada } \\
\text { manfaat }\end{array}$ & 11 & 45.8 & 13 & 42.3 & 24 & 100 & \\
\hline
\end{tabular}

Sumber : Data Primer 2018

Ancaman Penyakit dengan Pola Makan Pasien DM Tipe 2

Hubungan antara ancaman yang dirasakan dengan pola makan (asupan zat energi) dapat dilihat pada tabel 4. Dari tabel 4 menunjukkan bahwa penderita DM type 2 terbanyak dengan asupan energi kurang dan merasa tidak terancam berjumlah $81.2 \%$ (13 orang) dan yang merasa terancam sebanyak $64.3 \%$ (27 orang) sedangkan untuk penderita DM type 2 yang asupan energi cukup dan merasa terancam sebanyak $35.7 \%$ (15 orang) sedangkan untuk yang merasa tidak terancam sebanyak $18.8 \%$ (3 orang), dengan hasil statistik nilai $p$ value $0.342 \quad(p<0.05)$, sehingga dapat disimpulkan bahwa tidak ada hubungan antara ancaman yang dirasakan dengan asupan energi.

Sedangkan hubungan antara ancaman dengan pola asupan karbohidrat dan protein yang lebih serta asupan lemak yang cukup pada pasien DM tipe 2 memiliki hubungan. 
Penderita DM type 2 yang asupan karbohidrat lebih dan merasa tidak terancam sebanyak $75 \%$ (12 orang) sedangkan untuk yang merasa terancam sebanyak $38.1 \%$ (16 orang), dengan hasil statistik nilai $p$ value 0.012 $(p<0.05)$, sehingga dapat disimpulkan bahwa ada hubungan antara ancaman yang dirasakan dengan asupan karbohidrat (Lihat Tabel 5).

Tabel 4. Hubungan ancaman yang dirasakan dengan pola makan (Asupan Energi) penderita DM type 2.

\begin{tabular}{|c|c|c|c|c|c|c|c|}
\hline \multirow{3}{*}{$\begin{array}{c}\text { Ancaman yang } \\
\text { dirasakan }\end{array}$} & \multicolumn{4}{|c|}{ Asupan Energi } & \multirow{2}{*}{\multicolumn{2}{|c|}{ Jumlah }} & \multirow{3}{*}{$p$ value } \\
\hline & \multicolumn{2}{|c|}{ Kurang } & \multicolumn{2}{|c|}{ Cukup } & & & \\
\hline & $\mathrm{N}$ & $\%$ & $\mathrm{~N}$ & $\%$ & $\mathrm{n}$ & $\%$ & \\
\hline $\begin{array}{c}\text { Merasa } \\
\text { Terancam }\end{array}$ & 15 & 35.7 & 27 & 64.3 & 42 & 100 & 0.342 \\
\hline $\begin{array}{l}\text { Merasa Tidak } \\
\text { Terancam }\end{array}$ & 3 & 18.8 & 13 & 81.2 & 16 & 100 & \\
\hline
\end{tabular}

Tabel 5. Hubungan ancaman yang dirasakan dengan pola makan (Asupan Karbohidrat) penderita DM type 2.

\begin{tabular}{|c|c|c|c|c|c|c|c|}
\hline \multirow{3}{*}{$\begin{array}{c}\text { Ancaman yang } \\
\text { dirasakan }\end{array}$} & \multicolumn{4}{|c|}{ Asupan Karbohidrat } & \multirow{2}{*}{\multicolumn{2}{|c|}{ Jumlah }} & \multirow{3}{*}{$p$ value } \\
\hline & \multicolumn{2}{|c|}{ Cukup } & \multicolumn{2}{|c|}{ Lebih } & & & \\
\hline & $\mathrm{N}$ & $\%$ & $\mathrm{n}$ & $\%$ & $\mathrm{n}$ & $\%$ & \\
\hline Merasa Terancam & 16 & 38.1 & 26 & 61.9 & 42 & 100 & \\
\hline $\begin{array}{l}\text { Merasa tidak } \\
\text { terancam }\end{array}$ & 12 & 75 & 4 & 25 & 16 & 100 & \\
\hline
\end{tabular}

Sumber : Data Primer 2018

Penderita DM type 2 dengan asupan lemak yang cukup dan merasa terancam sebanyak $68.8 \%$ (11 orang) sedangkan untuk yang merasa tidak terancam sebanyak $33.3 \%$ (14 orang), dengan hasil statistik nilai $p$ value $0.015(p<0.05)$, sehingga dapat disimpulkan bahwa ada hubungan antara ancaman yang dirasakan dengan asupan lemak. Sedangkan untuk penderita DM type 2 yang terbanyak dengan asupan protein lebih dan merasa tidak terancam sebanyak $31.2 \% \quad$ (11 orang) sedangkan untuk yang merasa terancam sebanyak $2.4 \%$ (1 orang), dengan hasil statistik nilai $p$ value $0.005 \quad(p<0.05)$, sehingga dapat disimpulkan bahwa ada hubungan antara ancaman yang dirasakan dengan asupan protein.

\section{PEMBAHASAN}

Hasil penelitian yang di lakukan di Rumah Sakit Pendidikan Unhas Kota 
Makassar pada bulan Agustus-September 2018 tentang pola makan pada pasien rawat jalan penderita DM type 2 menunjukkan bahwa sebagian besar responden mempunyai pola makan yang cukup baik serta asupan zat gizi makro yang tergolong baik. Tujuan penelitian ini adalah untuk mengetahui hubungan pola makan penderita DM type 2 dengan pengetahuan, manfaat dan ancaman yang dirasakan pada 58 responden penderita DM yang melakukan pengobatan rawat jalan. Sampel di ambil secara acak berdasarkan jumlah penderita DM type 2 yang melakukan pemeriksaan pada saat penelitian berlangsung tanpa memperhatikan strata sehingga peneliti tidak perlu menyeimbangkan jumlah responden laki-laki dan perempuan.

Berdasarkan data pada tabel 2 menunjukkan bahwa pada variabel dengan jumlah terbanyak dengan pengetahuan cukup yang merasa terancam sebanyak $77.8 \%$ (14 orang) dan untuk pengetahuan baik sebanyak $70 \%$ (28 orang). Sedangkan jumlah terbanyak untuk pengetahuan yang baik dan merasa tidak terancam berjumlah $30 \%$ (12 orang) dan yang pengetahuan cukup yang merasa tidak terancaman berjumlah $22.2 \%$ (4 orang), dengan nilai $p$ value $0.391>0.05$ maka dapat disimpulkan bahwa tidak ada hubungan antara pengetahuan dan ancaman yang di rasakan.
Rosenstock serta Becker dan Maiman dalam Potter \& Perry tahun 2010 memiliki health belief model yang membahas hubungan antara anggapan individu dan tingkah lakunya. Model ini memungkinkan pengetahuan dan perkiraan cara tingkah laku penderita sehubungan dengan kesehatannya dan bagaimana mereka akan mematuhi suatu terapi layanan kesehatan. Menurut teori health belief model, modifying factor (faktor modifikasi ) pengetahuan yang lebih kuat dalam mendorong orang untuk mengadopsi perilaku sehat. Semakin besar acamanan yang dirasakan, semakin besar kemungkinan terlibat dalam perilaku untuk mengurangi resiko (Rahma, 2017).

Beberapa penelitian menunjukkan bahwa kurangnya pengetahuan tentang DM menyebabkan pasien Cenderung untuk tidak mematuhi pengobatan, diet dan insulin (Kong, Yein \& Jenn, 2012). Pengetahuan tingkat awal yang harus diperkenalkan pada pasien DM adalah perjalanan penyakit DM, pengendalian dan pemantauan DM, penyulit DM, terapi farmakologi dan non farmakologis, interaksi antara asupan makanan dengan aktifitas fisik serta olahraga, cara pemantauan glukosa darah mandiri, mengatasi hipoglikemia, pentingnya olahraga, perawatan kaki dan menggunakan fasiliitas kesehatan yang ada (PERKENI, 
2015).

Hal ini terkait dengan penelitian tentang perilaku dari Rogers yang dikutip oleh Notoatmodjo (2007) mengatakan bahwa pengetahuan atau kognitif merupakan domain yang sangat penting untuk terbentuknya tindakan atau perilaku seseorang. Pengetahuan penderita tentang diet diabetes melitus merupakan sarana yang dapat membantu penderita menjalankan penanganan diabetes melitus selama hidupnya sehingga semakin baik penderita mengerti tentang penyakitnya, semakin mengerti bagaimana harus berperilaku dalam penanganan penyakitnya (Muchid et al., 2015).

Hubungan akan pola asupan makanan dengan manfaat yang dirasakan oleh penderita DM Tipe 2, menunjukkan bahwa penderita DM type 2 terbanyak yang memiliki asupan energi kurang dan merasakan tidak ada manfaat berjumlah $54.2 \%$ (13 orang) dan yang merasa ada manfaat sebanyak $14.7 \% \quad$ (5 orang) sedangkan untuk penderita DM type 2 terbanyak dengan asupan energi cukup dan merasa ada manfaat sebanyak $85.3 \%$ (29orang) sedangkan untuk yang merasa tidak ada manfaat berjumlah $45.8 \%$ (11 orang) dengan hasil statistik nilai $p$ value pada hubungan manfaat yang dirasakan dengan asupan energi $p=0.001(p<0.05)$, sehingga kita dapat meyimpulkan bahwa ada hubungan antara manfaat yang dirasakan asupan energi.

Konstruksi manfaat yang dirasakan adalah pendapat seseorang dari nilai atau megunaan dari suatu perilaku baru dalam mengurangi risiko pengembangan penyakit. Orang-orang cenderung mengadopsi perilaku sehat ketika mereka percaya perilaku baru akan mengurangi risiko mereka untuk berkembangnya suatu penyakit. Setiap individu mempunyai cara yang berbeda dalam mengambil tindakan untuk penyembuhan atau pencegahan yang ditujukan untuk mengatasi gangguan kesehatan yang dirasakan.

Berdasarkan penelitian sebelumnya yang dilakukan oleh Alfiatur Rizki (Health Belief Model Pada penderita DM) pada subjek terdapat kesamaan manfaat yang dirasakan selama melakukan perilaku sehat sehingga subjek mau melakukan perilaku sehat adalah berkurangnya rasa nyeri pada tubuh ketika melakukan suntik insulin sesuai dengan anjuran dokter. Selain itu proses komplikasi yang terjadi pada keempat subjek dapat terhambat dengan adanya perilaku sehat yang dilakukan subjek.

Hubungan antara ancaman yang dirasakan dengan pola makan (asupan zat 
energi) dari tabel 4 menunjukkan bahwa penderita DM type 2 terbanyak dengan asupan energi kurang dan merasa tidak terancam berjumlah $81.2 \%$ (13 orang) dan yang merasa terancam sebanyak 64.3\% (27 orang) sedangkan untuk penderita DM type 2 yang asupan energi cukup dan merasa terancam sebanyak $35.7 \%$ (15 orang) sedangkan untuk yang merasa tidak terancam sebanyak $18.8 \%$ (3 orang), dengan hasil statistik nilai $p$ value $0.342 \quad(p<0.05)$, sehingga dapat disimpulkan bahwa tidak ada hubungan antara ancaman yang dirasakan dengan asupan energi. Sedangkan hubungan antara ancaman dengan pola asupan karbohidrat dan protein yang lebih serta asupan lemak yang cukup pada pasien DM tipe 2 memiliki hubungan.

Perceived threat of disease adalah keyakinan individu akan keparahan suatu penyakit. Sedangkan persepsi keparahan terhadap penyakit sering didasarkan pada informasi atau pengetahuan pengobatan, mungkin juga berasal dari kepercayaan terhadap orang yang memiliki kesulitan tentang penyakit yang diderita atau dampak dari penyakit terhadap kehidupannya (McCormick-Brown, 1999). Sebagai contoh, kebanyakan dari kita memandang flu sebagai penyakit ringan.

Berdasarkan penelitian yang di lakukan oleh Alfiatur Rizki responden sudah memiliki Percheived threat of disease baru mau melakukan perilaku sehat ketika responden sudah mengalami komplikasi. Karena responden terkesan meremehkan penyakitnya lantaran pada awalnya tidak mau menjaga pola makan dan gaya hidup, dengan bertambahnya beban pikiran karena pensiun, akhirnya subjek terkena stroke. Dan subjek mulai menyadari bahwasa pola makan, gaya hidup, terapi pengobatan dan sering konsultasi itu sangat penting.

Beberapa penelitian mengemukakan bahwa diabetes melitus terjadi akibat tidak seimbangnya asupan energy, karbohidrat, dan protein. Penelitian Juleka tahun 2005 pada penderita diabetes mellitus yang dirawat inap di RSU Gunung Jati Cirebon menemukan bahwa bahwa penderita yang memiliki asupan energy lebih besar dari kebutuhannya mempunyai resiko 31 kali lebih besar untuk mengalami kadar gula darah yang tidak terkendali dibandingkan dengan penderita yang asupan energinya sesuai kebutuhan (Juleka, 2005).

Dari hasil penelitian yang dilakukan Nugraha pada Juli 2012 diperoleh asupan serat 91,5\% penderita DM rawat jalan di RSUDAM Provinsi Lampung masih rendah, serta diketahui sebanyak $78 \%$ penderita dengan kadar GDP tinggi dan sebanyak 89,8 
\% dengan kadar GDPP yang tinggi (Muliani, 2012).

Penyakit diabetes melitus akan mempengaruhi metabolisme karbohidrat, protein, dan lemak dalam tubuh. Perombakan glukosa dari simpanan protein dan lemak dalam tubuh dapat dilaku(Juleka, 2005)kan bila sel kekurangan glukosa. Hal ini akan berdampak pada penurunan berat badan dan fungsi mental bila persendian protein dan lemak dalam tubuh berkurang. Komplikasi yang sering terjadi pada penderita diabetes melitus adalah kardiovaskular, kerusakan mata, kerusakan saraf, dan ginjal. Kardiovaskular merupakan penyebab utama morbiditas dan mortalitas pada penderita diabetes melitus. Di samping itu kardiovaskular penyumbang terbesar pengeluaran biaya untuk penyakit diabetes melitus.

\section{KESIMPULAN DAN SARAN}

Berdasarkan hasil penelitian dapat disim pulkan bahwa pengetahuan pasien DM Tipe 2 di Rumah Sakit Unhas pada bulan Agustus-September tentang pola makan penderita DM tipe 2 tidak memiliki hubungan keterkaitan dengan ancaman penyakit DM yang dirasakan. Namun, terdapat hubungan antara manfaat yang dirasakan oleh pasien DM Tipe 2 dengan pola makan penderita DM Tipe 2. Hubungan antara ancaman yang dirasakan dengan pola makan penderita DM tipe 2 terdapat hubungan, sedangkan hubungan pola makan melalui asupan energi penderita DM tipe 2 dengan ancaman yang dirasakan tidak memiliki hubungan. Disarankan kepada pihak Rumah Sakit agar melaksanakan Konseling gizi bagi penderita dibetes melitus tentang segala asupan nutrisi dalam melaksanakan diet ataupun pengaturan pola.

\section{DAFTAR PUSTAKA}

Bagian Ilmu Penyakit Dalam, F. K. U. G. M. (2012). Buku Ajar Pendidikan Dokter Penyakit Dalam. In R. H (Ed.), Buku Ajar Pendidikan Dokter Penyakit Dalam (Pertama). Yogyakarta: Bagian Ilmu Penyakit Dalam, Fakultas Kedokteran Universitas Gadjah Mada.

Green, L. W., Brancati, F. L., \& Albright, A. (2012). Primary prevention of type 2 diabetes: integrative public health and primary care opportunities, challenges and strategies.

Juleka. (2005). Hubungan Pola Makan dengan pengendalian Kadar Glukos Darah Pengidap Diabetes Melitus Type 2 Rawat Jalan Di RSY Gunung Jati Cirebon. Universitas Gadjah Mada.

Media Gizi Masyarakat Indonesia. (2011). Pola makan dan aktivitas fisik dengan kadar glukosa darah penderita diabetes melitus tipe 2 rawat jalan di RSUP Dr.Wahidin Sudirohusodo Makassar, 1(1):52-8.

Muchid, A., Umar, F., Ginting, M. N., Basri, C., Wahyuni, R., Helmi, R., \& Istiqomah, 
S. N. (2005). Pharmaceutical care untuk penyakit diabetes mellitus. Departemen Kesehatan RI, 1-89.

Muliani, U. (2012). Asupan Zat-zat gizi dan Kadar Gula Darah Penderita DM Type 2 Di Poliklinik Penyakit Dalam RSUD Dr. H. Abdul Moelok Provinsi Lampung. Ndraha, S., Penyakit, D., Fakultas, D., Universitas, K., \& Wacana, K. (2014). Diabetes Melitus Tipe 2 Dan Tatalaksana Terkini, 27(2), 9-16.

PERKENI. (2015). Konsensus Pengendalian dan Pencegahan Diabetes Melitus Tipe 2 di Indonesia 2015. Perkeni. https://doi.org/10.1017/CBO978110741 5324.004

Provinsi, D. K. (2015). Laporan Kesehatan Provinsi Sulsel. In Profil Kesehatan Prov Sulsel (p. 194). https://doi.org/10.1007/BF00633902

Rahma, A., Hastuti, Y. D., \& Kedokteran, F. (2017). Gambaran Health Belief Pada Penderita Diabetes.

Rizqi, A., Psikologi, P. S., \& Psikologi, P. S. (2017). Health Belief Model Pada Penderita Diabetes Melitus.

WHO. (n.d.). Diabetes Melytus. Retrieved fromhttp://www.who.int/mediacentre/fa ctsheets/fs312/en/ 